Тетерін Костянтин Юрьйович аспірант кафедри регіональної політики та публічного адміністрування ОРІДУ НАДУ, вул. Генуезька, 22, м. Одеса, 65000, тел.: (048) 705-97-95, e-mail: kost373@ rambler.ru, https://orcid.org/0000-0001-7505$401 \mathrm{X}$

\title{
НОВИЙ СУСПІЛЬНИЙ ДОГОВІР, ЯК НАГАЛЬНА НЕОБХІДНІСТЬ ІСНУВАННЯ НЕЗАЛЕЖНОЇ УКРАЇНИ
}

Анотація. Необхідність виправлення помилок, зроблених у процесі конституційного становлення Української держави, $є$ нагальною потребою. Політичні сили пропонують різноманітні варіанти проведення конституційної реформи в Україні. Вони включають в себе як зміну об'єму повноважень органів влади, так i різні способи оновлення Основного Закону, не виключаючи ухвалення цілковито нового документу. Тотальне недотримання Конституції України суб’єктами влади привели державу та суспільство до системної кризи, 3 якої існує лише один вихід - ухвалення нової редакції Конституції України та формування усіх органів державної влади і місцевого самоврядування на новій конституційній основі.

Сьогодні провести успішну конституційну реформу без широкого громадського обговорення та безпосередньої участі політично незаангажованих експертів-конституціоналістів неможливо. Адже саме громадяни мають сформувати суспільне замовлення на нову Конституцію. Україна потребує нового суспільного договору між громадянами, закріпленого новою редакцією Конституції. Суспільний Договір як комплекс принципів та правил співжиття у суспільстві - це справа самого громадянського суспільства, а влада - лише система забезпечення захисту та реалізації інтересів суспільства. Нову редакцію Конституції має створити громадянське суспільство через своїх повноважних представників, які беруть на себе виконання політичних функцій у державі, i мусять їх дотримуватися. Усвідомлення цього змушує вважати, що вихід 3 конституційної кризи можливий лише за умови ухвалення нової Конституції як реалізації установчої влади народу на основі принципу верховенства права. Також, є альтернатива прийняття до існуючої Конституції доповнення у вигляді політико-правового документа, яким буде Хартія 3 прав людини на зразок аналогічного документу, який існує в СС. Але обмежитись тільки цим неможливо, хоча в Хартії можна передбачити і кодифіковану частину у вигляді статей як у 
конституції з класичною будовою. Мається на увазі саме будова статей, в яких буде гіпотеза, диспозиція та санкція. Також, можна буде передбачити і частину, яка буде основана на прецеденті. Так як час не стоїть на місці, передбачити все неможливо, у зв’язку з виникненням нових відношень, які повинні регулюватися в рамках правових норм. Іншими словами, Конституція може бути прийнята на основі Нового Суспільного Договору, Національної Хартії 3 прав людині та громадянина, в кодифікованому вигляді, та Національного Кодексу етичної поведінки громадян. Такі документи будуть направлені на посилення ролі громадянського суспільства.

Ключові слова: Суспільний Договір, Публічний Договір, Новий Суспільний договір, Конституції, громадянське суспільство.

Teterin Konstantin Yuriovych postgraduate student of the Department of regional policy and public administration Regional Odessa Institute of Public Administration NAPA, Genoese St., 22, Odessa, 65000, tel.: (048) 705-97-95, e-mail: kost373@rambler.ru, https://orcid.org/0000-0001-7505-401X

\section{THE NEW SOCIAL CONTRACT AS AN URGENT NEED FOR THE EXISTENCE OF INDEPENDENT UKRAINE}

Abstract. The need to correct the mistakes made in the process of constitutional formation of the Ukrainian state is an urgent need. Political forces offer various options for constitutional reform in Ukraine. They include both a change in the scope of authority of the authorities and various ways to update the Basic Law, without excluding the adoption of a completely new document. Total non-compliance with the Constitution of Ukraine by the authorities has led the state and society to a systemic crisis, from which there is only one way out - the adoption of a new version of the Constitution of Ukraine and the formation of all state and local authorities on a new constitutional basis.

Today, it is impossible to carry out a successful constitutional reform without a broad public discussion and the direct participation of politically neutral constitutional experts. After all, it is the citizens who must form a public order for a new Constitution. Ukraine needs a new social contract between citizens, enshrined in the new version of the Constitution. The Social Contract as a set of principles and rules of coexistence in society is a matter of civil society itself, and power is only a system of ensuring the protection and realization of the interests of society. The new version of the Constitution should be created by civil society through its authorized representatives, who assume the performance of political functions in the state and must abide by them. Awareness of this leads us to believe that a way out of the constitutional crisis is 
possible only if the new Constitution is adopted as the implementation of the constituent power of the people on the basis of the rule of law. Also, there is an alternative to adopting an amendment to the existing Constitution in the form of a political and legal document, which will be the Charter of Human Rights like a similar document that exists in the EU. But it is impossible to limit oneself to this, although the Charter can provide for a codified part in the form of articles as in the constitution with a classical structure. This refers to the structure of the articles, which will be a hypothesis, disposition and sanction. Also, it will be possible to provide a part that will be based on precedent. Since time does not stand still, it is impossible to predict everything, due to the emergence of new relationships, which must be governed by law. In other words, the Constitution can be adopted on the basis of the New Social Contract, the National Charter of Human and Civil Rights, in codified form, and the National Code of Ethical Conduct for Citizens. Such documents will be aimed at strengthening the role of civil society.

Keywords: Social Contract, Public Contract, New Social Contract, Constitutions, civil society.

Постановка проблеми. Необхідність виправлення помилок, зроблених у процесі конституційного становлення Української держави, $\epsilon$ нагальною потребою. Політичні сили пропонують різноманітні варіанти проведення конституційної реформи в Україні. Вони включають в себе як зміну об'єму повноважень органів влади, так і різні способи оновлення Основного Закону, не виключаючи ухвалення цілковито нового документу. Тотальне недотримання Конституції України суб'єктами влади привели державу та суспільство до системної кризи, з якої існує лише один вихід - ухвалення нової редакції Конституції України та формування усіх органів державної влади і місцевого самоврядування на новій конституційній основі.

Сьогодні провести успішну конституційну реформу без широкого громадського обговорення та безпосередньої участі політично незаангажованих експертів-конституціоналістів неможливо. Адже саме громадяни мають сформувати суспільне замовлення на нову Конституцію. Україна потребує нового Суспільного Договору між громадянами, закріпленого новою редакцією Конституції. Суспільний Договір, як комплекс принципів та правил співжиття у суспільстві, - це справа самого громадянського суспільства, а влада - лише система забезпечення захисту та реалізації інтересів суспільства. Нову редакцію Конституції має створити громадянське суспільство через своїх повноважних представників, які беруть на себе виконання політичних функцій у державі, i мусять їх дотримуватися. Усвідомлення цього змушує вважати, що вихід 3 конституційної кризи можливий лише за умови ухвалення нової Конституції як 
реалізації установчої влади народу на основі принципу верховенства права. Також, є альтернатива прийняття до існуючої Конституції доповнення у вигляді політико-правового документа, яким буде Хартія 3 прав людини на зразок аналогічного документу, який існує в СС. Але обмежитись тільки цим неможливо, хоча в Хартії можна передбачити і кодифіковану частину у вигляді статей як у конституції з класичною будовою. Мається на увазі саме будова статей, в яких буде гіпотеза, диспозиція та санкція. Також, можна буде передбачити і частину, яка буде основана на прецеденті. Так як час не стоїть на місці, передбачити все неможливо, у зв'язку з виникненням нових відношень, які повинні регулюватися в рамках правових норм. Іншими словами, Конституція може бути прийнята на основі Нового Суспільного Договору, Національної Хартії 3 прав людині та громадянина, в кодифікованому вигляді, та Національного Кодексу етичної поведінки громадян. Такі документи будуть направлені на посилення ролі громадянського суспільства.

Мета статті. розкрити концептуальні засади Нового Суспільного Договору, який вкрай необхідний для організації взаємодії держави та суспільства на сучасному етапі існування України, як правової незалежної держави.

Аналіз останніх досліджень і публікацій. Розробкою концепцій суспільного договору займались ще 3 давніх часів. Засновниками, яких були: Платон, Аристотель, Томас Гоббс, Джон Локк, Ж. -Ж. Руссо, Пауль Анри Гольбах. В наш час над компонентами концепції Суспільного Договору працювали такі науковці сучасності: Аболіна Т.Г., Бакштановский В.I., Прилуцька А.С.,Капустін Б.Г., Луман Н., Согомонов Ю.В., Шрейдер Ю.А.

Виклад основного матеріалу. На сучасному етапі, в існуючих наукових джерелах та мас-медіа, застосовуються кілька назв, а саме: Суспільний Договір та Публічний Договір. Назва Суспільний Договір являється застарілою, хоча засновники теорії взаємодії держави та суспільства виклали свої концепції під такою назвою. Публічний Договір - більш сучасна назва. В часи заснування теорії суспільного договору такий документ не був формалізований у вигляді паперового документу. Теорія суспільного договору являла собою систему поглядів та принципів взаємодії влади та громадян в негласному вигляді, відповідно до існуючих звичаїв та традицій. Зараз використовують назву Публічний Договір, хоча і Суспільний Договір, якщо його формалізувати у вигляді документу, можна називати публічним, так як і основні дійові особи політичного процесу, і цілі, які вони намагаються досягти, є однакові. Таке тлумачення $є$ вірним, тому що в цих документах застосовується однаковий понятійно-категорійний апарат. Тому, на перший погляд, хоча різні назви, але ж при знайомстві зі змістом вказаних документів, можна зробити висновок про їх однаковість. Назва публічний договір стала популярною останнім часом завдяки 
мас-медіа, але віддаючи шану засновникам договірної теорії, будемо використовувати назву суспільний договір.[1]

Суспільний Договір повинен існувати безпосередньо як текст, на якому буде базуватися Конституція та інші закони. Суспільний Договір - це не одноразовий текст угоди, це натуралізований інститут домовленостей і пере домовленостей громадян.

3 плином часу теорія суспільного договору зазнавала змін. Так в часи Гоббса теорія суспільного договору являла собою ідеї авторитарної монархії. Теорія Локка захищала ідеї ліберальної монархії. Суспільний договір Руссо базувався на ліберальному республіканізмі. На сучасному етапі в Україні діє модель суспільних відносин, яку запропонував Руссо, але справжнього Суспільного Договору від оголошення незалежності в Україні фактично не існувало. Суспільний договір незалежної України був абстрактним, фіктивним і не відображав потреби Українського суспільства. Через це в нашій країні біля 25-ти років, після прийняття існуючої Конституції, накопичувалися протиріччя, що переповнили можливі межи існування.

Референдум 1991 року констатував факт розпаду СРСР. Тому важко назвати суспільним договором і Конституцію 1996 року, яку ухвалили за одну ніч як компроміс між президентом Леонідом Кучмою та більшістю у Верховній Раді. Постає питання, яким чином народ приймав участь в укладанні такого договору. Не можна вважати Конституцію суспільним договором, якщо вона була прийнята не як Акт державності (установчий договір), а як закон, і не громадянами, а їх представниками у Верховній Раді України 28 червня 1996 року. Хоча на той час текст Конституції України був одним із кращих в Свропі. В ньому гарантувалися всі можливі права для кожного громадянина країни. Однак, час показав, що гарантовані права були тільки декларативні. Держава не змогла забезпечити реалізацію в повній мірі прав людини та громадянина, не через дефіцит політичної волі, а через нові економічні відносини, коли держава втратила важилі керування політичним процесом, через недостатню комунікацію між державними інституціями та громадянським суспільством, через зневагу громадської думки.

В Україні укоренилася хибна політична традиція, яка виражається в тому, що коли політик обирається, то дає різноманітні обіцянки з урахуванням громадської думки, а після обрання, керується власними корисними мотивами при здійсненні повноважень. Хоча президент обирається прямим голосуванням, традиція володарювати одноособово, без огляду на суспільство, не виходить із свідомості більшості обраних президентів. Можна згадати такі слова: деспотизм призводить до свободи, свобода породжує анархію, а анархія в свою чергу повертає до деспотизму. Такий хід перебігу історичного процесу є неминучим за відсутністю гармонічної моделі взаємодії влади та суспільства. [2] 
Так як Конституція не виносилася на Всеукраїнській референдум, а участь громадянського суспільства в ухваленні Основного закону була обмежена, можна стверджувати, що суспільного договору немає i $\epsilon$ лише якісь негласні домовленості між учасниками політичного процесу. Таким чином, в Україні ніколи не існував легітимний Суспільний договір між громадянами та державою. Причина в наступному: ми не створювали державу з нуля, нам дісталася вся інфраструктура (державна, ресурсна, освітня та інша) від моделі СРСР.

Деякі захисники нинішньої моделі державності вважають, що в Україні існує "попередній позитивний консенсус на поза правовій основі". Іншими словами, ми погодилися, за замовчуванням, жити разом у державі Україна. Ми себе співвідносимо з цією державою й ідентифікуємо себе як українці. I цього для опонентів Конституанти досить. Все інше має бути віднесено до компетенції еліт, які "повинні домовитись між собою". Але це жодною мірою не Суспільний договір. В українських умовах - це "договір між правлячою верхівкою, яка "володарює", та олігархічними групами. Цей договір визначається як "клептократичний консенсус" в форматі формули "негативний консенсус вузького кола правлячого класу на поза правовій основі". У спрощеному варіанті такий "нелегітимний договір" виглядає як: "Ви даєте нам панувати, а ми даємо вам виживати".[3]

Позиція політиків та бізнесменів, щодо змісту Суспільного Договору, суттєво відрізняється від позиції простих людей, так як у них різні підходи до процесів взаємодії влади та суспільства. До розробки Суспільного Договору в Україні залучалось широке коло експертів, які пропонували різні концепції, згідно яких потрібно обрати вектор руху на шляху розробки положень згаданого документу. Значна частина суспільства підтримує такі перетворення в суспільному житті, а саме: революційні зрушення та зміни Конституції України.

3 моменту здобуття Україною незалежності відбувалися два протилежні, але взаємопов’ язані процеси - періодичні зміни Конституції і протести та революції.

З 1996 року в Україні діяла Конституція, яка закріплювала президентськопарламентську форму правління. У 2004 році, на тлі Помаранчевої революції, відбувся тиск з боку незалежних проукраїнських політичних сил, лідерами яких були В.Ющенко та Ю.Тимошенко, а 3 боку колоніальних проросійських політичних сил В.Янукович, що призвів до прийняття нової Конституції, яка спричинила перехід від президентсько-парламентської до парламентськопрезидентської форми правління.

Після того, як у 2010 році було обрано В. Януковича новим Президентом, відбувається нелегітимне скасування цих змін Конституційним судом та повернення до Конституції 1996 року, тобто до президентсько-парламентської форми правління. Президент України був орієнтований на зв’язки з Росією і тому 
приділяв мало уваги розбудові власних збройних сил та флоту, національній безпеці, допустив руйнування зв’язності та політичної рівноваги між регіонами України $з$ огляду на самостійну політичну лінію. Непослідовність політичної лінії Президента призвела до глибокої політичної кризи. Це проявилось на початку руху до європейської спільноти, а потім відмови вступати до угоди про асоціацію з ЄС.

Як наслідок, вказана криза призвела до Революції гідності в 2013-2014 роках, після якої Парламент України відновив Конституцію 2004 року, тобто парламентсько-президентську модель. Водночас, бойові дії на сході України змусили українців, в умовах цейтноту, обрати Президентом олігарха, який відтворив владу олігархів в Україні, і що, зрештою, призвело, в квітні 2016 року, до контрреволюційного перевороту в Парламенті. [4]

Нинішня ситуація в Україні характеризується тривалими бойовими діями на сході України, анексією Криму. Українців убивають на не оголошеній війні. Влада неспроможна ані перемогти, ані завершити цю війну. Відомо, що кожна війна закінчується перемовами про мир, навіть у випадках, коли одна із сторін була переможена, тому що з різних боків існують не тільки політичні гасла та ідеологічні спрямування, а й життя простих людей.

Народ, що формально є сувереном в Україні, не має можливості визначати своє майбутнє, бо влада є олігархічною та не спроможною вирішувати проблеми суспільства. У Конституції не міститься жодної відповідальності вищих посадовців за їхні дії. Гідність людини та громадянина в Україні принижується щодня несправедливістю, бідністю, брехнею. [5]

Попередні зміни у політичному житті країни не змогли усунути такі важливі обставини: по-перше, неспроможність привілейованого класу України створити справедливу республіку, в якій би був забезпечений суверенітет, цілісність країни, не корумпованість держави, стратегічне самостійне управління; по-друге, не отримання громадою справедливості, справжнього самоуправління та контролю над суспільним надбанням, в результаті двох здійснюваних, так би мовити, революцій, адже революція передбачає зміну пануючого класу. Такої зміни по факту не відбулось. В результаті революційних зрушень олігархічну владу повинен був змінити середній клас, до якого входить більшість громадян, хоча $\mathrm{i}$ визначення середнього класу в Україні $є$ дуже спірним. Так як, відповідно до показників, які є визначальними у розвинутих країнах, дуже складно віднести до середнього класу значну частину громадян України, яких більшість соціологів відносить до вказаного класу. Незважаючи на це, можна констатувати, що ознаки революційності в русі спочатку були. В результаті накопичених протиріч, влада не спромоглася керувати по-новому, а суспільство вже не могло жити за старих умов. Відмова від європейського курсу була тою іскрою, яка привела до 
повалення влади. Але в той же час, Верховна Рада України, будучи «клубом по інтересам великих власників» спромоглася частково взяти під контроль революційні процеси. Ця обставина і призвела до того, що революція гідності не спромоглася змінити суспільні відношення у державі. Люди, які щиро підтримували революцію гідності, були не просто розчаровані, а i розчавлені таким положенням справ. Чому люди підтримували революцію гідності можна зрозуміти під час детального аналізу рушійних факторів, які спонукали до громадянського протесту. Більшість вже не могла погодитись 3 корумпованістю влади, проте основною обставиною стало економічне положення кожного українця. Надія на входження до європейської спільноти дала б змогу підняти стандарти рівня життя, захищеності прав людини і громадянина. Влада посилалась на те, що немає для таких стандартів ресурсного забезпечення, але це не відповідає дійсності. Потрібно було справедливо розподіляти та перерозподіляти національні багатства. Більшість людей сподівалось, що зі вступом в європейську спільноту українці зможуть вільно пересуватись в межах європейського союзу. До речі, більшість таких громадян - це заробітчани із депресивних регіонів, які вимушені виїжджати в інші країни на роботу, з тим щоб прогодувати свої сім’і. Були і громадяни, які сподівалися, що при вступі до ЄС вони зможуть по розумних цінах придбати товари, які не виробляються нашою країною. Сподівання ці не були втіленні у життя, і тому багато хто зараз має подвійне громадянство, хоча в Україні це заборонено. Загроза державності якраз i полягає в тому, що країна втрачає основний людський ресурс. Українці масово залишають країну, з тим щоб знайти кращу долю в інших країнах, працюючи на благо останніх. [6]

У 2013-2014 роках, після Революції гідності, виникли ряд громадських рухів, які підтримують ідею нової Республіки. Серед них найбільш відомі - "Народна Конституція" і "Хартія майбутнього". Ці групи спричинили процес творення нової Конституції поза впливом привілегійованого класу. Розроблені ними документи, в тому числі закон про Конституанту, парламентською більшістю саботується. Ситуація змінилася коли після 2014 року почалися незворотні процеси не тільки у владі, а і у більшості політично-активної частини суспільства. Це дозволило почати розробку Суспільного Договору та Конституції, але водночас і значно політизувало процес.

Зараз більшість олігархів використали можливість для збагачення за рахунок роздержавлення власності, продажу будь-чого за кордон, i тому безпосередньо створили та продовжують створювати монополіі, тим самим заробляючи капітали нечесним шляхом. Це все більш посилює залежність громадян від економічно пануючого класу: підвищення тарифів, зростання цін, збільшення податків на середній клас, обмеження підприємницької ініціативи. 
Всі спроби шляхом реформ та покращень подолати кризу зі збереженням існуючого політико-правового змісту держави приречені на поразку. Ця система відтворює лише над токсичну атмосферу в суспільстві, яка вбиває будь-які зміни на краще та віру в спільне майбутнє. Накопичується тотальна недовіра та зрада, що руйнують бажання жити разом на цій території. Ми вже на межі тотального розпаду й автономізації. Такі зміни до Конституції вже не врятують, оскільки вони зводяться виключно до перерозподілу владних повноважень і не торкаються засадничих принципів: як і для чого нам жити разом. [7]

Тому, єдиним виходом із ситуації колапсу державності є іï пере заснування шляхом укладання фіксованого Нового Суспільного Договору. У його основі має лежати свідомий акт людини, яка бере на себе певні зобов'язання дотримуватися норм і принципів співжиття. I це має бути не "пакт еліт" чи домовленості між державою, бізнесом та громадянами, а саме угода між людьми і для людей.

Найболючішим питанням українців є тема тотальної корупції в державі. Можна сподіватися, що Новий Суспільний Договір стане основою, яка врятує Україну від цієї проблеми. Але для цього має бути прописаний механізм, коли i яким чином застосовується процедура боротьби з корупцією в рамках не тільки державних інституцій, а i в рамках громадянського суспільства, 3 тим щоб надійно забезпечити права та свободи людини та громадянина.

Проти формування та реалізації нових положень Суспільного Договору виступають не тільки олігархи та корумповані політики, а й експерти та журналісти, які перебувають на утриманні олігархів. Вони розгорнули широкий тролінг в соціальних мережах на фоні замовчування конституційного процесу на українському телебаченні. Водночас Інститут демократії та розвитку «РolitA» спільно 3 «Foundation for future» (Фундамент для майбутнього) вчетверте ініціювали публічне обговорення теми Нового Суспільного Договору, як життєво необхідного документу.

Реалізація положень цього політико-правового документу покладається на державний апарат. Виходячи з багаторічного досвіду, можемо констатувати, що державний апарат по своїй суті надзвичайно дисциплінований i, при чіткій постановці завдань, втілить в життя принципи і положення Нового Суспільного Договору. Головне, щоб політики, зокрема, і майбутні кандидати в Президенти, прислухались до експертного середовища і змогли запропонувати громадянам цей політико-правовий документ, який врахує інтереси кожного. Новий Суспільний Договір дозволить Україні перейти від суб'єктивного до об'єктивного діалогу на міжнародному рівні і стати рівноправним гравцем у геополітичному просторі.

Інноваційна суть Нового Суспільного Договору в край необхідна для перезаснування Української держави нового типу з оглядом на досвід країн європейського союзу. Україна повинна створити не тільки концепцію, відповідно 
до якої буде прийнята Декларація гідності, де буде закріплено як головний принцип - людина є вільною, Україна має право творити власне майбутнє, громадяни мають силу, волю та мужність щоб здійснити та оборонити свій вибір.

Насамперед, потрібно самовизначитися як вільним громадянам, а не народу, заснувати не державу, а спочатку Республіку, потім - державу. Головною метою на цьому шляху стане самореалізація кожного, а не абстрактна свобода, як згадувалося до цього. Потрібно буде домовитись про недомінацію, а не про рівність. Також необхідно закріпити курс на самоуправління, а не на представницьку демократію. Головним в інноваційному плані буде спрямування на співволодіння та співуправління спільним, а не отримування базового доходу 3 держбюджету. Тобто, нова спільна мета буде сформульована як повна та гідна самореалізація кожного у суверенному Ладі в гармонії з суспільством, Людством та Природою.

Так як принцип недомінації означає унеможливлення домінування однієї волі над іншою волею, він торкається лише тих, хто домовився про недомінацію та дотримується цієї домовленості (за межами домовленості діє домінація). Тому потрібна домовленість між усіма учасниками політичного життя. В економіці недомінація унеможливлює будь-яку монополію як те, що заважає конкуренції. Громади (договірні спільноти), що об'єднуються у межах територій, та здійснюють самоуправління, як місцеве, так i екстериторіальне, поступово позбавляють державу монополії на надання інфраструктурних послуг і створюють ринок цих послуг через сервісні муніципальні об’єднання. [8]

Новим Суспільним Договором буде закріплено, що кожний громадянин України є співвласником українського спільного надбання. Все, крім приватної власності, $є$ предметом нашого спільного співволодіння, і кожний громадянин, учасник цього Договору, має право прямого співуправління цим спільним надбанням.

Висновки. Через втрачання владою реального шансу на втілення реформ, виникла потреба суспільству брати не тільки участь в розробці Нового Суспільного Договору, а й конкретно скеровувати процес прийняття такого політико-правового документу. Організацію мас населення потрібно доручити органам місцевого самоврядування, так як такі органи охоплюють по територіальному принципу практично все населення нашої країни. Складання Нового Суспільного Договору слід розпочинати в спеціалізованих групах. Експерти і фахівці сформулюють і проаналізують усі положення договору. Після внесення змін, запропонованих громадськістю, викристалізується остаточний варіант Суспільного Договору, який можна буде виносити на Всеукраїнський Референдум.

Держава має перетворитися на платформу надання сервісів громадянам 3 
управління спільним, розподілом ресурсів та оборони.

Шлях руху України на тривалу перспективу в Новому Суспільному Договорі можна поділити на три етапи:

Перший етап. Прийняття Декларації гідності, нової Конституції, Національної Хартії з прав людини та громадянина, Національного Кодексу етичної поведінки громадян нової Республіки, інвентаризувати та впорядкувати національне суспільне надбання, що включає приватну власність та спільне надбання, а також створити умови для переходу до співволодіння та співуправління цим спільним надбанням прозорим договірним чином;

Другий етап. Входження у співволодіння спільним надбанням та заснування механізмів співуправління цим надбанням на договірній основі.

Третій етап. Забезпечення функціонування принципів та системи співволодіння та співуправління. Україна буде однією 3 перших держав, яка застосує принцип соціальних інновацій в сфері володіння та розподілу національного надбання. Такий процес Україна повинна проводити з огляду на світову практику найбільш успішних країн.

\section{Лimepamypa:}

1. Фуллер Лон Л. Анатомія права. / Пер. з англ .. Н.Комарової. - К .: Сфера, 1999.

2. Максимов С.І. Правова реальність: досвід філософського осмислення: Монографія. Харків: Право, 2002.

3. Стьопін В.С. Саморозвиваючі системи і некласична раціональність // Питання філософії. - 2003. - № 8.

4. Добронравова I.С., Білоус Т.М., Комар О.В. Новітня філософія науки: підручник для студ. філос. фак. ун-тів і аспірантів - К .: Логос 2009.

5. Недоцук Н.А. Філософія права: Конспект лекцій. / Упоряд. Н.А. Недоцук. - М .: Ексмо, 2006.

6. Поляков А.В. Загальна теорія права: феноменолого-комунікативний підхід. Курс лекцій. 2-й тип. Еxtra - Санкт-Петербург: Преса Юридичного центру, 2003.

7. Курс лекцій. 2-е вид. Доп. - СПб: Юридичний центр Прес, 2003.

8. Шульженко Ф. П., Андрусяк Т. Г. Історія політичних і правових вчень. - К.: Юрінком Інтер, 1999. - 304c.

\section{References:}

1. Fuller Lon L. (1999 ) Anatomiya prava. [Anatomy of Law]. / Per. from English. N. Komarova. - K .: Cфepa, ..Kyiv, [in Ukrainian].

2. Maximov S.I. (2002) Pravova real'nist': dosvid filosofs'koho osmyslennya [Legal reality: the experience of philosophical thinking]: Monograph. - Kharkiv: Pravo,. [in Ukrainian].

3. Stepin V.S. (2003) Samorozvyvayuchi systemy ta neklasychna ratsional'nist' // Pytannya filosofiyi [Self-developing systems and non-classical rationality // Questions of philosophy]. - № 8. Kyiv, [in Ukrainian].

4. Dobronravova I.S. Belous TM, Komar O.V. (2009) The latest philosophy of science: a textbook for students. philos. fac. universities and graduate students [The latest philosophy of science: 
a textbook for students. philos. fac. of universities and graduate students]- $\mathrm{K}$.: Logos. Kyiv, [in Ukrainian].

5. Nedotsuk N.A. (2006) [Philosophy of Law: Lecture notes.] - Moscow: Exmo, [in Russia].

6. Polyakov A.V. (2003) Zahal'na teoriya prava: fenomenoloho-komunikatyvnyy pidkhid. [General theory of law: phenomenological-communicative approach.] Course of lectures. 2nd type. Extra - St. Petersburg: Legal Center Press, [in Russia].

7. Course of lectures. (2003) 2nd type. Extra - St. Petersburg: Legal Center Press,- Moscow, [in Russia].

8. Shulzhenko F.P., Andrusyak T.G. (1999), Istoriya politychnykh i pravovykh vchen' [History of political and legal doctrines] : Jurinkom Inter,. - 304p. Kyiv, [in Ukrainian]. 